CHAD G. MARZEN*

\title{
Disqualifications in Horse Racing
}

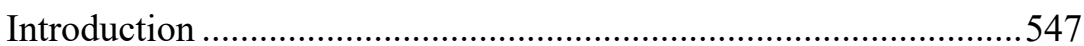

I. Grounds for Disqualification of Horses ...............................551

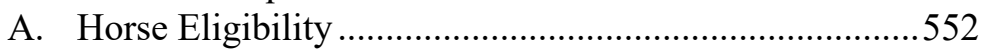

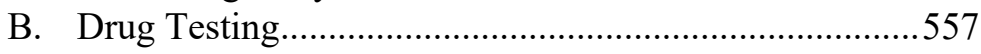

C. Interference and Riding Fouls ....................................561

D. Miscellaneous Other Grounds........................................565

II. The 2019 Kentucky Derby-An Analysis of West $v$.

Kentucky Horse Racing Commission .....................................568

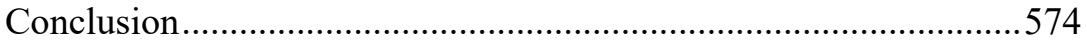

\section{INTRODUCTION}

The 2019 Kentucky Derby was the 145 th running $^{1}$ of the most venerable event in the "sport of kings," 2 and horse racing observers and sports enthusiasts will likely discuss its controversial outcome for years to come. ${ }^{3}$ Initially, the winner of the May 4, 2019, race appeared to be Maximum Security —a horse at nine-to-two odds. ${ }^{4}$

\footnotetext{
* Associate Professor of Legal Studies in Business, Florida State University, College of Business - Department of Risk Management/Insurance, Real Estate, and Legal Studies. The author can be reached at cmarzen@fsu.edu.

The author would like to thank the staff of the Oregon Law Review for the exceptional diligence and care assisting with the editing of this Article.

1 Joe Drape, Country House Wins Kentucky Derby After Maximum Security Is Disqualified, N.Y. TIMES (May 4, 2019), https://www.nytimes.com/2019/05/04/sports/ kentucky-derby-live.html [https://perma.cc/674R-QWQY].

2 Michael Kilian, The Evolution of the Sport of Kings, CHI. TRIB. (May 4, 1988), https://www.chicagotribune.com/news/ct-xpm-1988-05-04-8803140377-story.html [https://perma.cc/R62G-SJJ2] ("In the beginning, horse racing actually was the sport of kings, and the first jockey was himself a king.").

3 See Drape, supra note 1.

4 Country House Wins Kentucky Derby After Favorite DQ'd, REUTERS (May 4, 2019, 4:25 PM), https://ca.reuters.com/article/sportsNews/idCAKCN1SA0SV-OCASP [https:// perma.cc/NR7C-HTES].
} 
Maximum Security's owners even received a bouquet of roses, as it appeared the horse was the clear winner. ${ }^{5}$ After a twenty-two-minute review of the race, the stewards disqualified Maximum Security for interference and declared Country House, a horse at sixty-five-to-one odds, the official winner of the Kentucky Derby. ${ }^{6}$ After the disqualification, the bouquet of roses was taken away from Maximum Security's co-owner, Mary West, and placed around the neck of Country House. ${ }^{7}$ The Derby's outcome stunned thousands of individuals in attendance at Churchill Downs, resulted in a chorus of boos from the crowd, ${ }^{8}$ and left the co-owners of Maximum Security in disbelief. ${ }^{9}$

The impact of the stewards' momentous disqualification decision was enormous. Patrons lost millions of dollars in bets on Maximum Security due to the reversal of the race's finish. ${ }^{10}$ Maximum Security's co-owner, Gary West, called the disqualification decision "the most egregious disqualification decision in the history of horse racing." 11

5 Rick Bozich, Country House's DQ Victory No Roses for Kentucky Derby, WDRB.COM (May 4, 2019), https://www.wdrb.com/derby_145/bozich-country-house-s-dq-victory-noroses-for-kentucky/article_69334fc0-6edb-11e9-9c3c-ffb2d11ba2eb.html [https://perma. cc/9TSM-TYEF].

6 Francesca Paris, Country House, A 65-1 Long Shot, Wins Kentucky Derby After Historic Disqualification, NPR (May 4, 2019, 8:02 PM), https://www.npr.org/2019/05/04/ 720315488/country-house-a-65-1-long-shot-wins-kentucky-derby-after-historicdisqualificati [https://perma.cc/48GL-JGCZ].

7 Chuck Culpepper, 'The Worst Thing You Can Do Is Rush': Inside the Strangest 22 Minutes in Kentucky Derby History, WASH. Post (May 6, 2019, 4:44 PM), https://www.washingtonpost.com/sports/the-worst-thing-you-can-do-is-rush-inside-thestrangest-22-minutes-in-kentucky-derby-history/2019/05/06/54e011b0-701c-11e9-8be0ca575670e91c_story.html [https://perma.cc/X7CR-99Y7].

8 Robert Kieckhefer, Controversy Swirls Over Kentucky Derby Finish After Disqualification, UPI (May 4, 2019, 10:28 PM), https://www.upi.com/Sports_News/2019/ 05/04/Controversy-swirls-over-Kentucky-Derby-finish-after-disqualification/5261557013745/ [https://perma.cc/ZQS9-TT6A].

9 Scott Stump, Maximum Security Owner Says He Will Appeal Kentucky Derby Disqualification, TODAY (May 6, 2019, 5:00 AM), https:/www.today.com/news/ maximum-security-owner-gary-west-will-appeal-kentucky-derby-disqualification-t153573 [https://perma.cc/6ASE-ARGC] (quoting the reaction of Gary West, the owner of Maximum Security, as "[w]e were stunned, shocked, and in complete disbelief").

10 Jenna West, Maximum Security's Kentucky Derby Disqualification Cost Bettors \$9 Million, SPORTS IlLUSTRATED (May 5, 2019), https://www.si.com/horse-racing/2019/05/ 05/maximum-security-kentucky-derby-disqualification-bets-money-lost [https://perma.cc/ L25G-M49D].

11 Gary B. Graves, Maximum Security Owner Weighs Legal Options After 'Egregious' Kentucky Derby Result, WASH. TiMES (May 5, 2019), https://www.washingtontimes.com/ news/2019/may/5/gary-west-maximum-security-owner-weighs-legal-opti/ [https://perma. cc/BSZ3-GDQK]. 
A chorus of individuals has criticized the decision, ${ }^{12}$ including President Donald Trump, who expressed his disagreement with the decision in a tweet. ${ }^{13}$ Despite this criticism, many horse racing experts have opined that the stewards made the appropriate decision under the circumstances. ${ }^{14}$

On May 6, 2019, Mr. West promptly appealed the stewards' disqualification decision, but the Kentucky Horse Racing Commission almost immediately denied West's appeal. ${ }^{15}$ On May 14, 2019, Mr. and Mrs. West filed a lawsuit in the U.S. District Court for the Eastern District of Kentucky. They alleged, among other things, that the Kentucky Horse Racing Commission violated their procedural due process rights, and that the stewards abused their discretion in

12 E.g., Dick Jerardi, Maximum Security, the Best Horse in the Kentucky Derby, Shouldn't Have Been Disqualified, PHILA. INQUIRER (May 4, 2019), https://www.inquirer. com/sports/kentucky-derby-maximum-security-disqualification-analysis-country-house20190505.html [https://perma.cc/2HFZ-ERES]; Andy Nesbitt, Kentucky Derby: Controversial Ruling Is a Gigantic Embarrassment to the Sport of Horse Racing, USA TODAY (May 4, 2019, 7:58 PM), https://ftw.usatoday.com/2019/05/kentuckyderby-maximum-security-embarrassing-finish-ruling [https://perma.cc/L36J-ZT6D]; Dan Wolken, Opinion: Maximum Security Was Robbed at Kentucky Derby, Yet Another Black Eye in Horse Racing, USA TODAY (May 4, 2019, 10:52 PM), https://www.usatoday.com/ story/sports/columnist/dan-wolken/2019/05/04/kentucky-derby-2019-maximum-securityrobbed-racing-takes-another-hit/1105796001/ [https://perma.cc/J4U2-HE8V].

13 Ryan Gaydos, Kentucky Derby Appeal of Disqualification Ruling Denied by Officials, FOX NEwS (May 6, 2019), https://www.foxnews.com/sports/kentucky-derby-maximumsecurity-owner-total-disbelief [https://perma.cc/Q4GF-T5SL]. President Donald Trump tweeted the following:

The Kentucky Derby decision was not a good one .... It was a rough and tumble race on a wet and sloppy track, actually, a beautiful thing to watch. Only in these days of political correctness could such an overturn occur. The best horse did NOT win the Kentucky Derby — not even close!

Id.

14 E.g., Mike Brunker, Kentucky Derby Disqualification Was the Right Call, LAS VEGAS REV.-J. (May 7, 2019, 2:33 PM), https://www.reviewjournal.com/sports/sports-columns/ mike-brunker/kentucky-derby-disqualification-was-the-right-call-1658190/ [https://perma. cc/W6JP-GAQW]; Andrew Cohen, The Kentucky Derby Decision Might Avert Disaster, ATLANTIC (May 6, 2019), https://www.theatlantic.com/ideas/archive/2019/05/kentuckyderby-decision-may-avert-disaster/588814/ [https://perma.cc/HAE3-2MJY]; Gregory A. Hall, Kentucky Derby Opinion: Right Call, Wrong Process, BloodHorse (May 5, 2019), https://www.bloodhorse.com/horse-racing/articles/233517/kentucky-derby-opinion-rightcall-wrong-process [https://perma.cc/6T9N-6W5T]; Joshua M. Silverstein, On the Kentucky Derby Disqualification, Nw. ARK. DemOcrat GazetTe (May 12, 2019, 1:59 AM), https://www.nwaonline.com/news/2019/may/12/on-the-kentucky-derby-disqualification-/ [https://perma.cc/ND2P-ZNTS].

15 Gary B. Graves, Commission Denies Maximum Security Disqualification Appeal, ASSOCIATED PRESS (May 6, 2019), https://www.apnews.com/304ba0fea57540a5b13651fd 772d6b75 [https://perma.cc/U4M4-XUWD]. 
disqualifying Maximum Security. ${ }^{16}$ Because of the highly controversial nature of the stewards' disqualification decision, it is no surprise that litigation ensued to contest the outcome of the race.

West v. Kentucky Horse Racing Commission illustrates a situation that has occurred surprisingly often in horse racing throughout the years: a disqualification decision in a horse race that results in a lawsuit. Legal scholars have written extensively on the subject of horse racing, including articles about the historical and legal development of horse racing, ${ }^{17}$ the trainer responsibility rule in horse racing, ${ }^{18}$ medication rules for racehorses, ${ }^{19}$ the issue of performance-enhancing drugs and steroids in horse racing, ${ }^{20}$ and the regulation of horse racing in general. ${ }^{21}$ Multiple legal scholars have published works relating to the sale of horses. ${ }^{22}$ This Article makes a novel contribution to the law

16 Complaint at 5, 27, West v. Ky. Horse Racing Comm'n, No. 5:19-cv-00211-KKC (E.D. Ky. May 14, 2019) [hereinafter West Complaint].

17 E.g., Joan S. Howland, Let's Not "Spit the Bit" in Defense of "The Law of the Horse": The Historical and Legal Development of American Thoroughbred Racing, 14 MARQ. SPORTS L. REV. 473 (2004).

18 E.g., Bennett Liebman, The Trainer Responsibility Rule in Horse Racing, 7 VA. SPORTS \& ENT. L.J. 1 (2007).

19 E.g., Laurel Benson, Note, Down the Stretch: Reining in State Approaches Toward a Universal Medication Rule for Racehorses, 4 KY. J. EQUINE, AGRIC., \& NAT. RESOURCES L. 155 (2012); Alexandra D. Logsdon, Note, Unbridled "Spirits": An Integrated Analysis of the Law, the Science, and the Future of Thoroughbred Medication, 6 KY. J. EQUINE, AgriC., \& NAT. RESOURCES L. 141 (2014).

20 E.g., Kyle Cassidy, Comment, Reining in the Use of Performance Enhancing Drugs in Horseracing: Why a Federal Regulation is Needed, 24 SETON HALL J. SPORTS \& ENT. L. 121, 123 (2014); Cody M. Conner, Note, Thoroughbred Horse Racing: Why a Uniform Approach to Drug Regulation Is Necessary, $10 \mathrm{KY}$. J. EQUINE, AGRIC., \& NAT. RESOURCES L. 111, 114 (2018); Bradley S. Friedman, Oats, Water, Hay and Everything Else: The Regulation of Anabolic Steroids in Thoroughbred Horse Racing, 16 ANIMAL L. 123, 123 (2009); Jennifer M. Jabroski, Note, Reining in the Horse Racing Industry: A Proposal for Federal Regulation of Steroid Use in Racehorses, 1 KY. J. EQUINE, AGRIC., \& NAT. Resources L. 67, 67-68 (2009); Amy L. (Williams) Kluesner, And They're Off: Eliminating Drug Use in Thoroughbred Racing, 3 HARV. J. SPORTS \& ENT. L. 297, 298 (2012); Kjirsten Lee, Transgressing Trainers and Enhanced Equines: Drug Use in Racehorses, Difficulty Assigning Responsibility and the Need for a National Racing Commission, 11 J. ANimal \& NAT. ResourCE L. 23, 23 (2015); John T. Wendt, Horse Racing in the United States: A Call for a Harmonized Approach to Anti-Doping Regulation, 25 J. LEGAL ASPECTS SPORT 176, 176 (2015).

21 See, e.g., Luke P. Breslin, Comment, Reclaiming the Glory in the "Sport of Kings"Uniformity Is the Answer, 20 SETON HALL J. SPORTS \& ENT. L. 297, 299 (2010); Courtney D. Hall, Track Conditions Uncertain: Analyzing the Need for the NLRB to Reassess Its Denial of Jurisdiction over the Horse Racing Industry, 20 SPORTS L.J. 71, 72 (2013).

22 See, e.g., Anne I. Bandes, Note, Saddled with a Lame Horse? Why State Consumer Protection Laws Can Be the Best Protection for Duped Horse Purchasers, 44 B.C. L. REV. 789, 789 (2003); Frank T. Becker, Non-Uniform Statutes Governing the Sale of Horses, 8 Ky. J. EQuine, Agric., \& NAT. ResourCes L. 1, 1 (2016); Zachary T. Broome et al., 
review literature on horse racing by comprehensively examining the various grounds for litigation in racehorse disqualifications. ${ }^{23}$

Part I of this Article discusses cases in which the grounds for horse disqualifications have been litigated. With questions ranging from horse eligibility, to failed drug tests, interference, riding fouls, and other miscellaneous grounds, disqualification occurs in a variety of unique situations. Part II of this Article examines the claims made in West v. Kentucky Horse Racing Commission and analyzes the possibility that the official outcome of the 2019 Kentucky Derby will be overturned. This Article concludes that, consistent with the findings in the vast majority of cases throughout the country, the official results of the 2019 Kentucky Derby will likely not be overturned because the stewards' disqualification of Maximum Security was not arbitrary and capricious.

\section{GROUNDS FOR DISQUALIFICATION OF HORSES}

Numerous cases from jurisdictions throughout the United States demonstrate the variety of reasons why horses may be disqualified before or after the conclusion of a race. In some cases, officials may find a horse ineligible for entry due to noncompliance with the racing rules in that particular jurisdiction. In other cases, a horse may fail a drug test. Officials may also disqualify horses due to interference or fouls committed during the actual running of the race. Finally, several cases involve unique fact patterns and disqualification questions, such as two horses wearing each other's saddle numbers during a race, ${ }^{24}$

Equine "Lemon" Law, 18 DRAKE J. AGRIC. L. 289, 290 (2013); John J. Kropp et al., Horse Sense and the UCC: The Purchase of Racehorses, 1 MARQ. SPORTS L.J. 171, 171 (1991); Sarah R. Sandberg, Comment, Globalized Horse Trade: A Need for Heightened Sophistication in the Equine Industry, 69 UMKC L. REV. 613, 613 (2001).

23 An outstanding law review article was written in 2005 by Professor Bennett Liebman that analyzes several cases wherein the courts upheld decisions by state horse racing commissions reversing the stewards' decisions. Several of the cases discussed in that article involved disqualifications, but this Article is the first to my knowledge that has comprehensively reviewed decisions with a specific focus on disqualifications. See Bennett Liebman, Reversing the Refs: An Argument for Limited Review in Horse Racing, 6 TEX. REV. ENT. \& SPORTS L. 23 (2005).

24 Tex. Racing Comm'n v. Marquez, No. 03-09-00635-CV, 2011 WL 3659092, at*1 (Tex. Ct. App. Aug. 19, 2011). 
a jockey possessing a prohibited device, ${ }^{25}$ and an error in a horse's handicap. $^{26}$

\section{A. Horse Eligibility}

In the Pennsylvania case Racing GAMbit, LLC v. State Horse Racing Commission, the issue was Cousin Stephen's eligibility to race at Philadelphia PARX. ${ }^{27}$ Although Cousin Stephen ran and won the fifth race at Philadelphia PARX on September 25, 2016, his win was challenged on eligibility grounds. ${ }^{28}$

Cousin Stephen had been purchased in a claiming race ${ }^{29}$ in New York at Saratoga Race Course less than one month earlier on August 31, 2016. ${ }^{30}$ According to a New York horse racing regulation, a claimed horse "shall not race outside New York State for a period of [thirty] days from the date of the claim or the end of the meeting at which it was claimed, whichever period of time is longer." 31 The claim meeting for Cousin Stephen ended on September 4, 2016, which meant that, under the rules, Cousin Stephen was technically ineligible to run at Philadelphia PARX on September 25, 2016. ${ }^{32}$

\footnotetext{
25 Jackson v. Ark. Racing Comm'n, 34 S.W.3d 740, 741 (Ark. 2001).

26 Kaufman v. Sarafan, 452 N.E.2d 1252, 1253 (N.Y. 1983); Kaufman v. Sarafan, 457 N.Y.S.2d 69, 69 (App. Div. 1982).

27 Racing GAMbit, LLC v. State Horse Racing Comm'n, 184 A.3d 192, 193 (Pa. Commw. Ct. 2018).

28 Id.

29 Horse Betting: Claiming Races, US RACING, https://www.usracing.com/horsebetting/claiming-race [https://perma.cc/2XM9-W2F3] (last visited Feb. 8, 2020).

This website explains a claiming race as follows:

A claiming race means that the horses may be purchased by a licensed owner for the claiming price listed for that race. Every track has certain claiming guidelines, but generally there are certain rules that apply. As well as being licensed, the person making the claim also must have enough money in their horsemens' bookkeeper account to pay for the horse, and they must have a trainer to pick up the horse after the race. To make the actual claim, the owner or his authorized agent will fill out a "claim slip" with the relevant information (date, race, horse name, owner name, etc.) and deposit the slip in the claim box. There is usually a deadline to drop your claim, generally [fifteen] minutes to post. In the event of [sic] more than one owner drops a claim on the same horse, the racing official in charge of claims, the claims clerk, will conduct a "shake" to determine who will become the new owner. The shake involves putting numbered pills, one representing each owner, in the pill bottle and pulling out a winning number. The horse is then picked up by its new owner/trainer after the race.

Id.

30 Racing GAMbit, LLC, 184 A.3d at 193-94.

31 Id. at 193.

32 Id.
} 
Nevertheless, the stewards declared Cousin Stephen the official winner of the race prior to receiving any challenge to his eligibility. ${ }^{33}$ Eleven days after the race, the owner of Richie's Rich - the secondplace horse-informed the chief steward that Cousin Stephen was ineligible. ${ }^{34}$ The stewards ruled that Cousin Stephen could not be disqualified because the protest was not timely received. ${ }^{35}$ Following an appeal by the owner of Richie's Rich, the Pennsylvania State Horse Racing Commission overturned the final race result on February 28, 2017, disqualified Cousin Stephen, and ordered the winnings of the race to be redistributed. ${ }^{36}$

The Pennsylvania Commonwealth Court reversed the Commission's ruling and concluded that the Commission went beyond merely examining the stewards' discretionary authority by "evaluat[ing] the merits of the appeal." 37 The Pennsylvania Commonwealth Court also noted that the Pennsylvania State Horse Racing Commission regulations grant stewards "the authority and discretion to handle matters in front of them" and the power to "disallow an untimely protest regarding racing qualifications or entries." 38 The Pennsylvania Commonwealth Court concluded that the "Commission erred as a matter of law in addressing the merits of the appeal after already concluding that the stewards did not abuse their discretion." ${ }^{39}$ Thus, Cousin Stephen retained his first-place finish. ${ }^{40}$

In another case, the court upheld the stewards' postrace decision to disqualify a horse named The Noble Player from the Henry P. Russell Handicap - a horse race in California - on eligibility grounds. ${ }^{41}$ The Henry P. Russell Handicap had an eligibility restriction in place that limited the race to horses under three years old that had not won more than $\$ 25,000$ in the year. ${ }^{42}$ Unknown to the stewards before the race, The Noble Player did not meet those eligibility requirements. Earlier that year, The Noble Player had placed first in the San Matean Handicap on September 15, 1984, winning a $\$ 22,400$ share of the

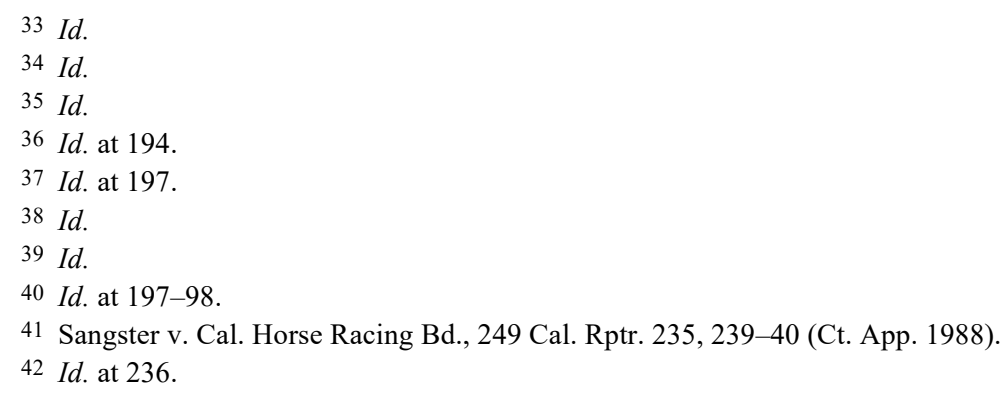


statutory $\$ 35,000$ purse and a $\$ 2,700$ portion of the Breeder's Cup Award for placing first in the race. ${ }^{43}$ Thus, The Noble Player's total winnings were $\$ 25,100 .{ }^{44}$

Ten days after the Henry P. Russell Handicap, an employee of the Santa Anita Race Track read in a magazine article that The Noble Player earned \$25,100 in the San Matean Handicap. ${ }^{45}$ The employee informed an official of the Oak Tree Racing Association, which sponsors the Henry P. Russell Handicap, and then the information was forwarded to the board of stewards. ${ }^{46}$ The stewards subsequently disqualified The Noble Player, and the California Horse Racing Board upheld the disqualification. ${ }^{47}$

On appeal, the California Court of Appeals examined the disqualification's timeliness. The owner of The Noble Player argued that protests must be submitted to the stewards within seventy-two hours of the race, pursuant to Rule 1754 of the California Administrative Code applicable to horse racing. ${ }^{48}$ Rule 1754 stated that the protest must be made by a "protestor," but the relevant definition of a "protestor" did not include stewards. ${ }^{49}$

The California Horse Racing Board contended that two other applicable rules justified the stewards' disqualification of The Noble Player. First, Rule 1750 gave the stewards the power to "make diligent inquiry or investigation into any complaint, objection or protest made either upon their own motion, by any racing official, or by any other person empowered by this chapter to make such complaint, protest or objection." ${ }^{50}$ Second, Rule 1592 provided that "[a]ny horse ineligible to be entered for a race, or ineligible to start in any race, who competes in such race may be disqualified and the stewards may discipline anyone responsible therefor." 51

\footnotetext{
$43 I d$.

44 Id.

$45 \mathrm{Id}$.

$46 \mathrm{Id}$.

47 Id. at $236-37$.

48 Id. at 237 . Rule 1754 stated the following: "A protest against any horse which has started in a race, shall be made to the stewards in writing, signed by the protestor, within 72 hours of the race exclusive of non-racing days of the meeting." Id.

49 Id. at 237-38. Rule 1756 stated the following: "A jockey, driver, trainer or owner of a horse which is entered for or is a starter in a race is empowered to file an objection or protest against any other horse in such race ...." Id.

50 Id. at 237.

${ }^{51} I d$.
} 
In analyzing those rules, the California Court of Appeals noted that the rules generally "confer a broad flexibility and discretion to resolve questions of eligibility." 52 Thus, the Sangster court held that a seventytwo-hour requirement for protests would impede the broad flexibility and discretion of stewards, and, therefore, the stewards in the case acted within a reasonable time in disqualifying The Noble Player. ${ }^{53}$

In Helad Farms v. Pennsylvania State Harness Racing Commission, the Pennsylvania Commonwealth Court overturned the disqualification of an owner's racehorses for failure to make staking payments when an employee waived the payment deadline for one owner at the disadvantage of other similarly situated horse owners. ${ }^{54}$ In the Helad Farms case, the racehorse owner engaged a New York staking agent to make staking payments ${ }^{55}$ in various jurisdictions to ensure the owner's horses were eligible to race. ${ }^{56}$ Although the staking agent timely submitted the racehorse owner's staking payment checks to the Pennsylvania State Harness Racing Commission, the checks were facially defective. ${ }^{57}$

On June 3, 1982, the State Harness Racing Commission eventually gave the staking agent twenty-four hours to correct the staking payments. ${ }^{58}$ The administrator of the Pennsylvania Sire Stakes Fundallegedly without the authorization of the State Harness Racing Commission - purportedly accepted a hand-delivered payment on or about June 3, 1982, from another horse owner for eight horses after that horse owner had learned of the defaults in the staking payments by the staking agent. ${ }^{59}$ Because the administrator of the Fund did not personally contact the other affected horse owners by June 3, 1982, they were not aware of the defaults by the staking agent; consequently,

$52 I d$. at 238.

$53 \mathrm{Id}$.

54 Helad Farms v. Pa. State Harness Racing Comm'n, 470 A.2d 181, 181 (Pa. Commw. Ct. 1984).

55 Id. at 183. The Helad Farms court described staking payments as follows:

In order to qualify for entry in the races supervised by the Commission, certain periodic nominating and sustaining payments must be made into the Pennsylvania Sire Stakes Fund (Fund) for each horse which the owner intends to race in the Sire events. These staking payments are to be made for each horse as a yearling in order to qualify that horse to run as a two or three year old.

Id. at 182 .

56 Id. at 183 .

57 Id.

$58 I d$.

59 Id. 
the Pennsylvania State Harness Racing Commission made the decision to disqualify nineteen horses. ${ }^{60}$

The Helad Farms court overturned the decision of the Pennsylvania State Harness Racing Commission and emphasized the Commission's duty to avoid preferential treatment as follows:

[T] he duty of the Commission to avoid conduct ... which would reflect negatively on the sport includes the obligation to avoid preferential treatment among horse owners whether wittingly or unwittingly. A preference, whether innocently or culpably granted, is generally the same in the eyes of the skeptic, and to the skeptical world is the equivalent of intentional preference. Such a preference, regardless of how effected, is unacceptable and, we believe, outside the scope of the Commission's discretion. While the default of the current agent is not the Commission's responsibility, avoidance of preferential treatment is. This could simply have been avoided by enforcement of its rules, rather than the granting to [the administrator of the Pennsylvania Sire Stakes Fund the] discretion to waive them. ${ }^{61}$

Thus, the Helad Farms court held "that the waiver of payment deadlines in this case, resulting to the advantage of one owner and thus to the disadvantage of others similarly represented, cannot be approved." 62

In Heavner v. Illinois Racing Board, an issue arose from entry of the horse Brookes Pride into the Cardinal Stakes race on May 28, 1980, in Illinois. ${ }^{63}$ In Heavner, an entry blank for Brookes Pride was not found in the entry box for the Cardinal Stakes at Sportsman Park. ${ }^{64}$ The owner of Brookes Pride contended the racing officials made a mistake, so the owner filed another entry blank for Brookes Pride. ${ }^{65}$ The race stewards rejected the new entry. ${ }^{66}$ The owner of Brookes Pride then filed a temporary restraining order-which was granted - enjoining the Sportsman Park management from interfering with Brookes Pride's participation in the race. ${ }^{67}$ The trial court eventually reversed the decision of the Illinois Racing Board to disqualify Brookes Pride. ${ }^{68}$

\footnotetext{
$60 \mathrm{Id}$.

$61 \mathrm{Id}$. at 184

$62 \mathrm{Id}$. at 185.

63 Heavner v. Ill. Racing Bd., 432 N.E.2d 290, 291 (Ill. App. Ct. 1982).

$64 \mathrm{Id}$.

$65 \mathrm{Id}$.

66 Id. at 292.

$67 \mathrm{Id}$.

$68 \mathrm{Id}$. at 290.
} 
Brookes Pride was thus allowed to run the race and finished second, winning a more than $\$ 60,000$ share of the purse. ${ }^{69}$ The owner of Brookes Pride contended that, because four of the Illinois Racing Board's rules were violated, the Board had waived strict compliance with the entry rules. ${ }^{70}$ In analyzing these arguments, the Illinois Court of Appeals focused in particular on Rule 12.21, which requires that a state steward or designated representative open the entry box for a race. ${ }^{71}$ The owner of Brookes Pride made the claim that neither a steward nor a representative of the steward was present at the opening of the Cardinal Stakes' entry box. ${ }^{72}$ The Heavner court held that, because Rule 12.21 ensures "the integrity of the entry process," the Illinois Racing Board made a reversible error by disregarding the part of the rule that requires a steward or steward's representative to open the entry box. ${ }^{73}$ Thus, the Heavner court found the Illinois Racing Board arbitrarily applied the rules. ${ }^{74}$

The Racing GAMbit LLC and Sangster cases illustrate a trend that has emerged from horse racing litigation: courts will generally uphold the postrace disqualification of a horse. An exception to that trend arises, however, when state horse racing boards and commissions apply rules arbitrarily, which occurred in the Helad Farms and Heavner cases.

\section{B. Drug Testing}

Another reoccurring basis for litigation arises from disqualifications based on drug tests that indicate the presence of a prohibited foreign substance in the horse. Although numerous lawsuits have challenged drug test disqualifications, the courts have routinely upheld those disqualification decisions.

Owners of disqualified horses have presented a number of different arguments in seeking to overturn disqualification decisions based on failed drug tests. One argument is that the presence of the substance did not have a material effect on the outcome of the race. An excellent recent example of this can be found in the facts of Ciresa $v$.

\footnotetext{
$69 I d$. at 292.

$70 \mathrm{Id}$.

71 Id. at 293. The Heavner court noted that Rule 12.21 stated: "The entry box shall be opened by the state steward, or his designated representative, at the advertised time. The state steward will be responsible to see that at least one horseman . . is present." Id.

$72 \mathrm{Id}$.

73 Id. at $294-95$.

74 Id. at 294.
} 
Pennsylvania State Horse Racing Commission. ${ }^{75}$ In Ciresa, the horse Cosmic Destiny was disqualified from a first-place showing in a race at Philadelphia PARX on October 11, 2016. Cosmic Destiny was disqualified after testing positive for carisoprodol, a prohibited muscle relaxant. ${ }^{76}$ The Pennsylvania State Horse Racing Commission even acknowledged that both sides of the expert testimony before the Commission revealed that the amount of carisoprodol found in the horse did not affect the horse's performance. ${ }^{77}$ Despite the fact that the carisoprodol appeared to have no effect on the race, the Pennsylvania Commonwealth Court upheld the Commission's affirmation of the stewards' disqualification because the very fact that carisprodol was in the horse violated the Commission's regulation. ${ }^{78}$ Thus, even though the regulation effectively imposed strict liability, the disqualification was appropriate. ${ }^{79}$

In some cases, a horse owner's failure to strictly comply with the rules and regulations of a state racing commission can result in the courts upholding a stewards' disqualification decision. In Glen Hill Farm, LLC v. California Horse Racing Board, the owner of a horse named Augment failed to timely file objections with the stewards as to Medici Code's qualifications to compete in the 2007 Del Mar Derby. ${ }^{80}$ Although Medici Code placed first in the Derby, Medici Code was subsequently disqualified from two prior races (a second-place showing in the Oceanside Stakes and a first-place showing in the La Jolla Handicap) due to positive test results for clenbuterol, ${ }^{81}$

75 Ciresa v. Pa. State Horse Racing Comm'n, No. 1155 C.D. 2017, 2019 WL 237414 (Pa. Commw. Ct. Jan. 17, 2019).

76 Id. at *1-2.

77 Id. at *3-4.

$78 I d$. at *6-7.

$79 \mathrm{Id}$.

80 Glen Hill Farm, LLC v. Cal. Horse Racing Bd., 117 Cal. Rptr. 3d 550, 553 (Ct. App. 2010).

81 See Kentucky Equine Research Staff, Clenbuterol Banned in Quarter Horse Racing, EQUINEWS (Jan. 12, 2015), https://ker.com/equinews/clenbuterol-banned-quarter-horseracing/ [https://perma.cc/M9FD-HJTU].

Clenbuterol (trade name Ventipulmin ${ }^{\circledR}$ ) is a bronchilator that is helpful for horses with heaves, an inflammatory condition that causes the airways to constrict. Horses with heaves have a hard time exhaling and are often intolerant of exercise.

Figuring that more air would be a benefit to racehorses, trainers have sometimes given clenbuterol to horses that did not have heaves. Use of this drug has not been shown to have a beneficial effect on breathing in healthy horses. Some side effects such as increased muscle mass, however, are believed to have a performanceenhancing role. 
a prohibited substance. ${ }^{82}$ The owner of Augment contended that Medici Code should not be the winner of the Del Mar Derby because had Medici Code been disqualified prior to the Del Mar Derby, it would never have qualified to enter the race. ${ }^{83}$

The California Court of Appeals in Glen Hill Farm, LLC remarked that an applicable rule stated that "the time limitation on the filing of protests shall not apply in any case in which fraud or willful misconduct is alleged provided that the stewards are satisfied that the allegations are bonafide [sic] and susceptible of verification." ${ }^{24}$ The owner of Augment failed to make an objection to the stewards on the basis of "fraud or willful misconduct" prior to filing objections with the California Board of Horse Racing. ${ }^{85}$ Because of this failure to file an objection to the stewards, the owner of Augment waived any right to a hearing before the California Board of Horse Racing. ${ }^{86}$

Racehorse owners have also lodged constitutional challenges to the applicability of the rules regarding foreign substances in horses. In Johnson v. Board of Stewards of Charles Town Races, Eastern Delite, the winner of a race at the 2007 West Virginia Breeders Classic, was disqualified for a positive caffeine drug test. ${ }^{87}$ The West Virginia Racing Commission had a rule in effect that prohibited "any drug substance . . f foreign to the natural horse." 88

The owners of Eastern Delite contended the zero tolerance rule for foreign substances was arbitrary, capricious, and unconstitutional, because the evidence in the case indicated the caffeine in Eastern Delite had no effect on the performance of the horse. ${ }^{89}$ The Supreme Court of West Virginia cited with approval ${ }^{90}$ the Illinois Court of Appeals' decision in Kline $v$. Illinois Racing Board, which upheld the constitutionality of a similar rule prohibiting "any foreign substance" in a horse. ${ }^{91}$ The Kline court reasoned that there was no reliable scientific method to calculate the effect of a substance on a horse in any given race, and that if horse racing boards and courts could consider

\footnotetext{
82 Glen Hill Farm, LLC, 117 Cal. Rptr. 3d at 552-53.

$83 \mathrm{Id}$. at 553.

$84 \mathrm{Id}$. at 556.

$85 \mathrm{Id}$.

86 Id.

87 Johnson v. Bd. of Stewards of Charles Town Races, 693 S.E.2d 93, 94 (W. Va. 2010).

$88 I d$. (emphasis in original).

$89 \mathrm{Id}$. at 95.

$90 \mathrm{Id}$. at 98.

91 Kline v. Ill. Racing Bd., 469 N.E.2d 667, 673 (Ill. App. Ct. 1984).
} 
the particular effects of a substance on any horse, then this "would necessarily result in almost endless conflicts before the winner of a race could be declared." 92 These conflicts would likely arise between medical experts before the Board of Horse Racing and legal experts in the courts. ${ }^{93}$ As the Supreme Court of West Virginia remarked, "[T]he winner of a horse race would not be determined by the speed of the horses on the track, but by the dexterity of experts and lawyers in the courtroom."94 The Supreme Court of West Virginia held that the zero tolerance rule "is a reasonable method of preventing horses from being raced when they have drugs in their system." 95

Horse owners have also raised arguments based on the Equal Protection Clause of the United States Constitution. Under the Equal Protection Clause, no state shall "deny to any person within its

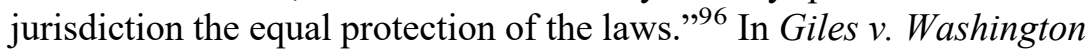
Horse Racing Commission, a rule promulgated by the Washington State Horse Racing Commission prohibited the medication phenylbutazone for two-year-old horses but not older horses. ${ }^{97}$ The Washington Court of Appeals upheld the regulation on rational basis review, noting that the "rule obviously applies equally to all owners of [two]-year old horses," and that the Washington State Horse Racing Commission is entrusted with the authority to establish rules and regulations for horse racing within the state. ${ }^{98}$ Finding a rational basis existed for the regulation, the Giles court noted that "the appropriate medication for horses entered in races is clearly of legitimate concern to the Commission." 99

In another case, the Kentucky Court of Appeals rejected an equal protection argument in Allen v. Kentucky Horse Racing Authority. ${ }^{100}$ In Allen, the State of Kentucky's regulations prohibited the medication flunixin in harness racing but not in thoroughbred racing. ${ }^{101}$ The Kentucky Horse Racing Authority held an administrative hearing about the disqualification of CR Commando from two harness races that took

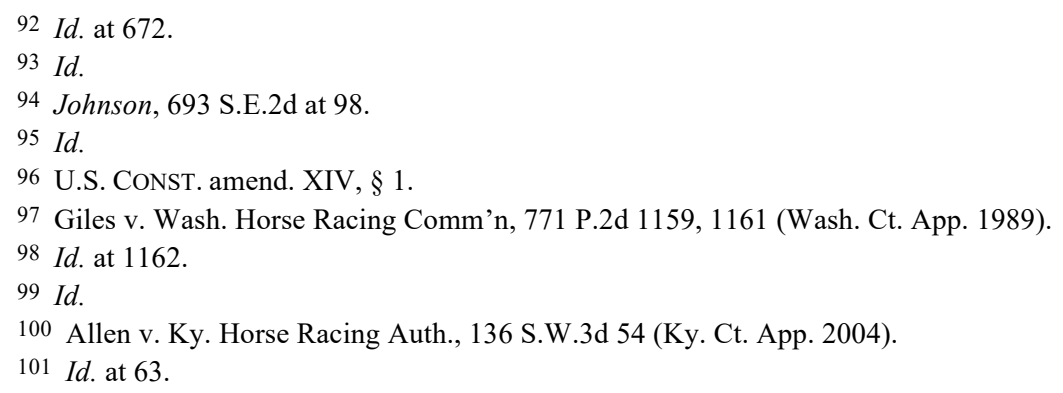


place in October 1998. ${ }^{102}$ At that hearing, a veterinarian with the Kentucky Horse Racing Authority testified that harness racing and thoroughbred racing are different, and that "the harness industry had to be careful that it did not allow a sore horse or a lame horse to mask its pain in a race because of the possibility of hurting other horses in the field in the event of an accident." ${ }^{103}$ The Allen court then concluded a rational basis existed to treat the harness and thoroughbred racing industries differently. ${ }^{104}$

In addition, horse owners have alleged due process violations arising from disqualifications based on the presence of foreign substances. The constitutional right to due process requires notice as well as a "meaningful opportunity to be heard."105 In Maryland Racing Commission v. Belotti, the owner of La Beau-a horse disqualified after testing positive for the prohibited drug furosemide - received no notice of the stewards' disqualification hearing. ${ }^{106}$ Despite the lack of notice for the stewards' hearing, the owner was given notice for a de novo administrative hearing concerning the disqualification before the Maryland Racing Commission. ${ }^{107}$ The Maryland Court of Appeals ultimately held that no due process violation had occurred. ${ }^{108}$

\section{Interference and Riding Fouls}

In addition to disqualification decisions based upon the presence of a foreign substance in a horse, a number of courts have reviewed disqualification decisions for interference and fouls that allegedly occurred during a race.

Courts typically uphold the disqualification decisions of both stewards and racing commissions in cases that involve either interference or riding fouls. A typical case exemplifying this rule is Jones v. New Mexico State Racing Commission. ${ }^{109}$ In the Jones case, the owner of a horse named Rule the Deck challenged the stewards' decision to disqualify Rule the Deck as winner of the 1982 World's Championship Quarter Horse Classic horse race, which took place on

\footnotetext{
$102 I d$.

$103 \mathrm{Id}$.

104 Id. at 64.

105 LaChance v. Erickson, 522 U.S. 262, 266 (1998).

106 Md. Racing Comm'n v. Belotti, 744 A.2d 558, 564-65 (Md. Ct. Spec. App. 1999).

107 Id. at $572-73$.

108 Id. at $576-78$.

109 Jones v. N.M. State Racing Comm'n, 671 P.2d 1145 (N.M. 1983).
} 
August 1, 1982. ${ }^{110}$ The stewards had disqualified Rule the Deck for "whipping" and "bumping" another horse approximately seventy-five yards after the start of the race. ${ }^{111}$ On appeal, the Supreme Court of New Mexico found the New Mexico State Racing Commission provided adequate notice ${ }^{12}$ and an impartial hearing ${ }^{113}$ to the horse owner, and that the disqualification decision was supported by substantial evidence. ${ }^{114}$ In particular, the Jones court found the New Mexico State Racing Commission "viewed the film of the race, heard testimony, and considered other evidence concerning the running of the race"; thus, the disqualification was upheld by substantial evidence and was not arbitrary and capricious. ${ }^{115}$

Judicial deference to stewards' decisions may even extend to situations in which the stewards have acknowledged a decisional error. ${ }^{116}$ On August 2, 1986, during a race at the Saratoga Race Course, the racehorse Allumeuse was wrongly disqualified for a foul that was actually committed by another horse. ${ }^{117}$ This mistake was even acknowledged by the stewards of the race. ${ }^{118}$ Subsequently, in Cramer v. New York State Racing Association, a group of pari-mutuel ticket holders filed suit against the New York State Racing Association and sought to have the result overturned and Allumeuse declared the official winner of the race. ${ }^{119}$

The ticket holders contended that the New York State Racing and Wagering Board acted arbitrarily in declining to reverse the stewards' disqualification decision. ${ }^{120}$ Despite the clear and unequivocal mistake by the stewards, an appellate court in New York noted that the New York State Racing and Wagering Board authorized the stewards to resolve all race objections and to declare an official winner. ${ }^{121}$ The

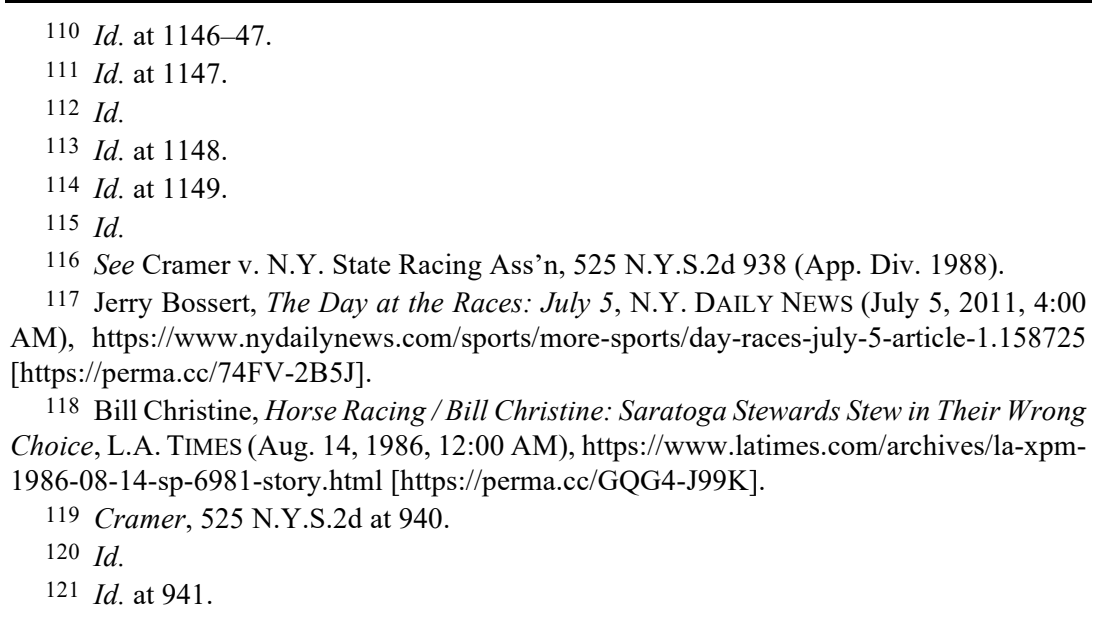


court noted that "the Stewards have been granted the final word concerning the official outcome of a race insofar as the pari-mutuel payoff is concerned," and, therefore, the official results could not be overturned by the court. ${ }^{122}$

In some cases, the owner of a non-first-place horse may object to the stewards that the first-place horse interfered. Such was the case in Lerman v. State Horse Racing Commission - a case that resulted from a thoroughbred horse race at Philadelphia PARX on January 31, $2017 .{ }^{123}$ In the Lerman case, the stewards did not disqualify the winner of the race because a bump between the first-place horse, Big Saver, and the second-place horse, S.S. Minnow, did not affect the outcome of the race. ${ }^{124}$ The Pennsylvania Commonwealth Court upheld the stewards' decision, holding that "the bumping between Big Saver and S.S. Minnow was generally-accepted contact incidental to horse racing that did not alter the Race's outcome." 125

Similarly, the Ohio Court of Appeals upheld a stewards' finding of no interference in Miller v. Ohio State Racing Commission. ${ }^{126}$ The owner of the horse named Bobby M. contended that another horse, Wall Street Dancer, interfered with Bobby M. during the Miller High Life Cradle Stakes race on September 3, 1990. ${ }^{127}$ The stewards disallowed the objection, and the Ohio State Racing Commission affirmed the stewards' decision. ${ }^{128}$

In reviewing the Commission's decision, the Ohio Court of Appeals acknowledged that both sides presented "substantial evidence" supporting their conclusions about the interference. ${ }^{129}$ In essence, each side presented an equally plausible case. The Miller court ultimately held in its most significant finding that the Ohio State Racing

122 Id. The Court also reasoned that "[t]his 'rule of finality' pertains only to the parimutuel payoff and, given the anonymous nature of the betting transaction, is necessary to preserve the financial integrity of the pari-mutuel system." Id. (citation omitted).

123 Lerman v. State Horse Racing Comm'n, No. 1362 C.D. 2017, 2018 WL 3431796 (Pa. Commw. Ct. July 17, 2018).

124 Id. at $* 1$.

$125 I d$. at *6.

126 Miller v. Ohio State Racing Comm'n, No. 94APE06-886, 1995 WL 89696 (Ohio Ct. App. Feb. 28, 1995).

127 Id. at $* 1$.

$128 I d$.

129 Id. at *3 ("The foregoing testimony, if believed, is substantial, reliable and probative evidence that not only was Wall Street Dancer clear of Bobby M. at the time of the alleged infraction, but that nothing in the way Madrid handled Wall Street Dancer impeded, intimidated or interfered with Bobby M. We fully recognize, however, that appellant presented substantial evidence to the contrary."). 
Commission committed no error in upholding the stewards' final decision that interference did not occur. ${ }^{130}$

Courts will also reject challenges to the stewards' nondisqualification decision if the horse owner fails to timely appeal. In Heft v. Maryland Racing Commission, the thoroughbred horse named Pulverizing finished second to Diamond Donnie in the Dancing Count Stakes on February 4, 1989. ${ }^{131}$ The owner of Pulverizing appealed to the Maryland Racing Commission, alleging Diamond Donnie interfered with two other horses in the race and that the interference should have disqualified Diamond Donnie. ${ }^{132}$ The objection was not filed within the time limit specified by a regulation that required objections to be made before the owner's jockey passed the scales. ${ }^{133}$ The Heft court specifically noted that "[ $\mathrm{t}]$ here is no provision in the regulations for excusing the time limits set forth in the regulations on the ground that neither the owner nor the trainer nor the jockey saw the violation of the Commission's rules." "134 Because the owner of Pulverizing did not file a timely objection — nor did the stewards take any action - the owner was not entitled to an appeal. ${ }^{135}$

At least one state supreme court - the Supreme Court of Montanahas overturned a stewards' disqualification decision for interference on due process grounds. ${ }^{136}$ In Smith v. Board of Horse Racing, Mickey's Hot Sauce was disqualified from first place for alleged interference in a thoroughbred horse race at the Budweiser Derby during the Montana State Fair. ${ }^{137}$ The owner of Mickey's Hot Sauce appealed the stewards' decision to the Board of Horse Racing, which upheld the stewards' disqualification ruling. ${ }^{138}$

In the Smith case, the stewards discussed the incident with the trainers of two other horses who were given the opportunity to present their arguments. ${ }^{139}$ The owner of Mickey's Hot Sauce, however, was not given an opportunity to discuss the incident with the stewards. ${ }^{140}$ The Smith court held that this was a violation of due process, and that

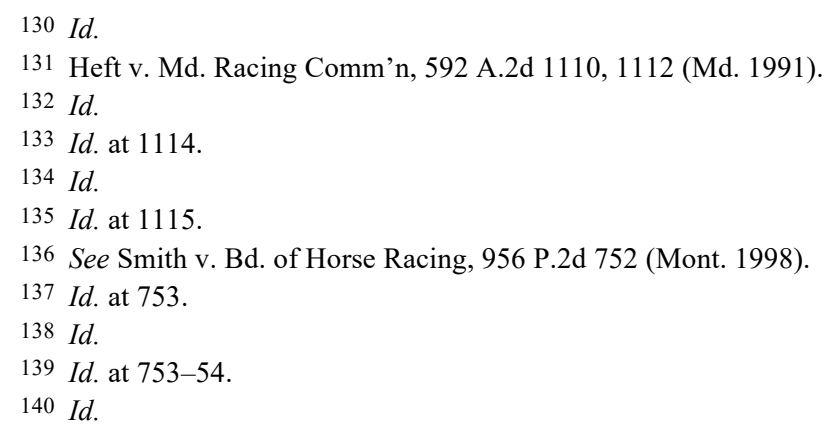


it was an error for the Board of Horse Racing to defer to the stewards' decision when both sides were not given an opportunity to be heard. ${ }^{141}$ The Smith court remanded the case to the Board of Horse Racing for a de novo hearing. ${ }^{142}$ Although the Smith court found a due process violation and overturned the stewards' decision, this is certainly a minority decision; in most cases, courts have upheld stewards' decisions as to interference disqualifications.

Although a significant number of cases in horse racing litigation comprise questions concerning horse eligibility, drug testing, interference, and riding fouls, other cases have involved issues outside these general categories.

\section{Miscellaneous Other Grounds}

Several disqualification cases involve unique fact patterns. For example, in Texas Racing Commission v. Marquez, two racehorses owned by the same owner inadvertently wore each other's saddlecloth numbers. ${ }^{143}$ This mistake was a violation of Texas Racing Commission rules, so the stewards disqualified both horses (one of the horses had finished second in the race). ${ }^{144}$ The Texas Racing Commission refused to consider the owner's appeal. ${ }^{145}$ The trial court held, however, that the Executive Director of the Texas Racing Commission exceeded her authority by refusing the appeal and ordered the distribution of the second-place purse to the owner. ${ }^{146}$

The Texas Court of Appeals in Marquez closely examined the statute that governed appeals of stewards' decisions ${ }^{147}$ and found that such appeals were allowed except in (1) cases that involve a "disqualification for a foul in a race" and (2) cases that involve findings "of fact regarding the running of a race." ${ }^{148}$ The Marquez court reasoned that because the statute mentioned that only disqualifications for a foul or facts regarding the running of a race are unappealable, it followed that other stewards' decisions are appealable. ${ }^{149}$ Thus, the

\footnotetext{
141 Id. at 754.

$142 I d$.

143 Tex. Racing Comm'n v. Marquez, No. 03-09-00635-CV, 2011 WL 3659092, at*1 (Tex. Ct. App. Aug. 19, 2011).

144 Id.

145 Id.

146 Id.

147 See id.

$148 I d$.

149 Id. at $* 5$.
} 
decision to disqualify the horses for wearing each other's saddlecloth numbers would be appealable. Accordingly, the Marquez court upheld the trial court's finding that the Executive Director of the Texas Racing Commission exceeded her authority in denying the appeal. But the court also held that the trial court lacked subject-matter jurisdiction to decide on the merits of the case until the owner exhausted his administrative remedies. ${ }^{150}$

Another unique case involved the absolute insurer rule - a rule in horse racing that makes horse trainers the absolute insurer of their horses, irrespective of the acts of jockeys or any other third parties. ${ }^{151}$ In Jackson v. Arkansas Racing Commission, the Supreme Court of Arkansas upheld the disqualification of Valhol as the first-place horse in the 1999 Arkansas Derby. Additionally, the court upheld the application of the absolute insurer rule. ${ }^{152}$ In the Jackson case, racetrack officials found a battery - a prohibited device - on the racetrack. ${ }^{153}$ After reviewing video footage of the race, track officials found that Valhol's jockey dropped an object on the track. ${ }^{154}$ After the stewards' inquiry, Valhol was disqualified, the jockey was suspended and fined, and the purse money from the Derby was redistributed. ${ }^{155}$

Valhol's owner appealed the disqualification decision of the Arkansas Racing Commission, but the trial court upheld the decision. ${ }^{156}$ On appeal to the Supreme Court of Arkansas, the horse's owner argued that the Arkansas Racing Commission lacked the authority to redistribute the purse because no rule explicitly authorized that sanction for that violation. ${ }^{157}$ The Jackson court agreed with the finding of the trial court, which remarked that the Arkansas Racing Commission "may take what action it deems necessary to supervise, regulate, and control, in the public's interest, horse racing." The Jackson court also opined that "stewards are empowered to punish

$150 I d$. at *5-6 ("In this context and given our conclusion that the director exceeded her authority by denying [the horse owner] an administrative appeal, we conclude that the trial court lacked subject matter jurisdiction to make further rulings . . . of the stewards' decision until [the horse owner] exhausts his administrative remedies.").

151 See, e.g., Luke P. Iovine, III \& John E. Keefe, Jr., Horse Drugging - The New Jersey Trainer Absolute Insurer Rule: Burning Down the House to Roast the Pig, 1 SETON HALL J. SPORT L. 61 (1991) (generally discussing the absolute insurer rule in New Jersey).

152 Jackson v. Ark. Racing Comm'n, 34 S.W.3d 740, 741 (Ark. 2001).

153 Id. ("A battery is a small electrical device that, if used, could alter the outcome of a race by increasing the horse's speed.").

154 Id.

$155 I d$.

156 Id.

157 Id. at 742. 
violations of those rules." ${ }^{258}$ Thus, the Jackson court found that redistribution of the purse was an appropriate sanction. ${ }^{159}$

Valhol's owner also argued that the violation resulted from the actions of his jockey and that the Arkansas Racing Commission both failed to meet the burden of proof for the sanction and violated the owner's constitutional due process rights by imposing that sanction. ${ }^{160}$ The owner contended that, before imposing the sanction, the Commission was required to make a factual finding that the violation involved complicity between the owner and the jockey. ${ }^{161}$

The Jackson court rejected both arguments, upholding the application of the absolute insurer rule. ${ }^{162}$ The Supreme Court of Arkansas previously upheld the constitutionality of the absolute insurer rule, ${ }^{163}$ and the Jackson case reaffirmed its applicability to horse racing in Arkansas. ${ }^{164}$ The Jackson court stated as follows:

Possession of the device violated rule 1214 [the rule prohibiting the possession of an electrical device during a race], and no other rule required the commission to find that [the horse owner] was aware his jockey possessed the device or that the device actually altered the race's outcome. Given the rule's violation, disqualification resulted. ${ }^{165}$

Therefore, the Arkansas Racing Commission did not act arbitrarily or capriciously, nor did they violate the owner's constitutional due process rights. $^{166}$

Another unusual disqualification occurred in Kaufman $v$. Sarafan. ${ }^{167}$ In Kaufman, a horse named Blazin' C was disqualified as the 1980 winner of a New York race. ${ }^{168}$ The disqualification resulted

\footnotetext{
158 Id. at $742-43$.

159 Id. at 743.

$160 \mathrm{Id}$.

$161 \mathrm{Id}$.

162 Id. at 744.

163 D'Avignon v. Ark. Racing Comm'n, 651 S.W.2d 87, 88 (Ark. 1983) (“We feel the enterprises of horse and dog racing are especially susceptible to fraud and deceit because of the parimutuel wagering. It is apparent that detection of the adulteration of an entrant prior to payment to the winning betters is not feasible and it is imperative that society be afforded as much protection as possible to prevent abuses. For these reasons, we find the absolute insurer (Rule 1233) a constitutional and valid exercise of the police power of this state.").

164 Jackson, 34 S.W.3d at 744.

$165 I d$.

166 Id.

167 See Kaufman v. Sarafan, 452 N.E.2d 1252 (N.Y. 1983).

168 Id. at 1253.
} 
from a handicap ${ }^{169}$ error. ${ }^{170}$ The Court of Appeals of New York-New York's appellate court of final appeal ${ }^{171}$-reaffirmed that the horse's owner was responsible for the handicap error, not the race secretary. ${ }^{172}$

All these cases illustrate that disqualifications after a horse race are not as rare as they may appear at first glance. The 2019 Kentucky Derby is an example of this phenomenon but on a much larger scale and with much more at stake.

\section{II}

\section{THE 2019 KENTUCKY DERBY-AN ANALYSIS OF WEST $V$. KENTUCKY HORSE RACING COMMISSION}

Maximum Security's disqualification from the 2019 Kentucky Derby was not the first controversial disqualification in Derby history. On May 4, 1968, Dancer's Image, a horse owned by Peter Fuller, crossed the finish line first in the Kentucky Derby. ${ }^{173}$ However, Dancer's Image was disqualified two days later because he tested positive for phenylbutazone, ${ }^{174}$ an illegal substance in horse racing at the time. ${ }^{175}$ Several theories surround this case, one of which suggests that Mr. Fuller was the victim of retaliation; more specifically, either Fuller's horse, the horse's feed, or the urine sample in question was

169 See Horse Betting: Graded Stakes and Handicap Races, US RACING, https://www. usracing.com/horse-betting/handicapping-stakes-races [https://perma.cc/2NQV-YY9F] (last visited Feb. 8, 2020) ("With handicap races, preference is given to those horses that have been assigned the most weight. The Racing Secretary assigns weights to horses in a handicap race, with the horses who have accomplished the most according to their past performances carrying the highest weight, while the least competitive horses will carry a lower weight. Assigning different weights is an attempt to level the playing field between competitors.").

170 Kaufman, 452 N.E.2d at 1253.

171 The Court of Appeals of the State of New York, CORNELL U. L. SCH., https://www.law.cornell.edu/nyctap/court/background.htm [https://perma.cc/MJ2C-XS2D] (last visited Feb. 8, 2020) ("The Court of Appeals, New York State's highest court, is composed of a Chief Judge and six Associate Judges, each appointed to a 14-year term.").

172 Kaufman, 452 N.E.2d at 1253.

173 T.D. Thornton, Revisiting Dancer's Image, N.Y. TIMES (May 3, 2008, 10:35 AM), https://therail.blogs.nytimes.com/2008/05/03/revisiting-dancers-image/ [https://perma.cc/ CMZ3-EPWA].

174 Sid Gustafson, Drugs and Racehorses, N.Y. TIMES (June 4, 2008, 3:42 PM), https:// therail.blogs.nytimes.com/2008/06/04/drugs-and-racehorses/ [https://perma.cc/7P3G-8HM6] ("Phenylbutazone, or bute, abbreviated from the early popular brand Butazolodin, is a nonsteroidal anti-inflammatory drug very similar to aspirin.”).

175 Thornton, supra note 173. 
intentionally tampered with because Fuller had supported civil rights. ${ }^{176}$

Mr. Fuller litigated the dispute and the Kentucky State Racing Commission upheld Dancer's Image's disqualification. ${ }^{177}$ The trial court then reversed the Commission, finding for Mr. Fuller. ${ }^{178}$ On appeal, the Kentucky Court of Appeals reviewed whether the Kentucky State Racing Commission met the "substantial evidence" standard when it upheld Dancer's Image's disqualification. ${ }^{179}$ The Fuller court remarked that the substantial evidence standard "is whether when taken alone or in the light of all the evidence it has sufficient probative value to induce conviction in the minds of reasonable men." 180 The court analyzed the expert testimony and the record, then held that "there was an abundance of substantial evidence supporting the findings and rulings of the Kentucky State Racing Commission."181 Thus, Mr. Fuller and Dancer's Image lost.

Approximately fifty-one years later, controversy again surrounded the Kentucky Derby when Maximum Security was disqualified for interference. Just like Mr. Fuller, Gary and Mary West have filed suit in the wake of Maximum Security's disqualification. ${ }^{182}$

The crux of the Wests' Complaint is that the stewards lacked substantial evidence to disqualify Maximum Security and that the disqualification violated the Wests' Fourteenth Amendment right to due process. ${ }^{183}$ The Wests allege that after the stewards read the disqualification statement

the Stewards refused to answer any questions that might theoretically shed light on the evidence on which they relied, the reasoning behind their disqualification, how their decision to disqualify satisfied the rules governing fouls, and the deliberative process by which they unanimously came to the conclusion to disqualify Maximum Security. ${ }^{184}$

\footnotetext{
176 Id.

177 Ky. State Racing Comm'n v. Fuller, 481 S.W.2d 298, 300 (Ky. Ct. App. 1972).

$178 \mathrm{Id}$.

$179 \mathrm{Id}$.

$180 \mathrm{Id}$. at 308.

181 Id. at 309.

182 Darran Simon, Owners of Kentucky Derby Horse Maximum Security File Lawsuit Seeking to Overturn the Disqualification, CNN (May 15, 2019, 11:27 PM), https://www.cnn.com/2019/05/15/us/maximum-security-kentucky-derby-lawsuit/index.html [https://perma.cc/HBS4-6HJG].

183 West Complaint, supra note 16.

184 Id. 96.
} 
The Wests claim that the stewards disqualified Maximum Security before they interviewed the two horse jockeys allegedly involved in the interference. The Wests also allege that the stewards failed to establish not only that the interference had occurred but also that the interference affected the race's finish. ${ }^{185}$

In their brief in support of a Motion for Summary Judgment, the Wests rely ${ }^{186}$ on the Louisiana Court of Appeals' decision in Ramsey v. Louisiana State Racing Commission. ${ }^{187}$ In Ramsey, a horse named Coalport fouled Benwill during the Unbridled Stakes horse race on September 6, 2014. ${ }^{188}$ Coalport won the race, but the stewards disqualified him. ${ }^{189}$ Coalport's owner conceded that Coalport committed a foul, but the question remained whether the foul altered the race's outcome. ${ }^{190}$ In Ramsey, the Louisiana Court of Appeals held that even though a foul occurred, "the foul 'did not alter the outcome of the race," " and that the Louisiana State Racing Commission applied the wrong standard of review in analyzing the stewards' disqualification. ${ }^{191}$ The Ramsey court noted that the Louisiana State Racing Commission committed legal error when it used an "indisputable evidence" standard instead of a "preponderance of the evidence" standard; thus, the courts gave no deference to the Louisiana State Racing Commission's determinations. ${ }^{192}$

Given the claims in the West case, the Kentucky State Horse Racing Commission will likely prevail, and the stewards' decision to disqualify Maximum Security should stand. As to the claim that the stewards' decision was arbitrary or capricious, a number of facts strongly weigh against any such finding. First, although the stewards did not discuss the incident with every jockey potentially affected by the interference, they did interview Luis Saez-the jockey of Maximum Security ${ }^{193}$ - and gave Saez the opportunity to present his version of the facts. Second, the stewards deliberated for approximately

185 Plaintiff's Brief in Support of Motion for Summary Judgment, West v. Ky. Horse Racing Comm'n, No. 5:19-cv-00211-KKC (E.D. Ky. May 31, 2019) [hereinafter West's Brief in Support of Motion for Summary Judgment].

186 Id. at $16-19$.

187 Ramsey v. La. State Racing Comm'n, 248 So. 3d 648 (La. Ct. App. 2018).

$188 \mathrm{Id}$. at 650.

$189 \mathrm{Id}$.

$190 I d$.

191 Id. at $652-53$.

$192 I d$. at 653.

193 See West's Brief in Support of Motion for Summary Judgment, supra note 185, at 7. 
twenty-two minutes, which indicates the stewards at least conducted a reasonable investigation into the incident. ${ }^{194}$

Those investigations are specifically left to the discretion of the stewards. Kentucky administrative regulations explicitly endow the stewards with the following powers:

- To " $[\mathrm{m}] \mathrm{ake}$ all findings of fact as to all matters occurring during and incident to the running of a race"; 195

- To "[d]etermine all objections and inquiries based on interference by a horse, improper course run by a horse, foul riding by a jockey, and all other matters occurring during and incident to the running of a race"; 196 and

- To "[d]etermine the extent of disqualification, if any, of horses in a race for a foul committed during the race." 197

The regulations also specifically state that the stewards' "findings of fact and determination shall be final and shall not be subject to appeal."198 These regulations presumably reflect the view that the stewards - not outside parties, such as judicial courts - are the experts best suited to make the intricate factual determinations as to whether interference or fouls have occurred.

As a baseball fan, I may love the game of baseball, and I may agree or disagree with an umpire's call when watching my beloved Kansas City Royals play baseball. But that would hardly qualify me to act as a major league baseball umpire, calling balls, strikes, and outs. And if the courts became involved with the balls and strikes of America's pastime, the unique experience and particular expertise of baseball umpires may be disregarded. ${ }^{199}$ Similarly, in horse racing, if the courts routinely reviewed the intricate factual determinations of stewards, then every owner of a horse that did not finish first in a race would be incentivized to search for an interference or foul that actually does not exist. As a public policy matter, courts should not insert their judgment into controversial finishes in horse racing or any other sport because it will leave the fans with uncertainty at the conclusion of a sporting event.

\footnotetext{
$194 \mathrm{Id}$. at 6.

195810 KY. ADMIN. REGS. 1:017 § 4(a) (2019) (repealed).

196 Id. $\S 4(\mathrm{~b})$.

197 Id. $\S 4(\mathrm{c})$.

198 Id. § 4(c)(2).

199 See Jim Caple, Humbled by Umpire School, ESPN (Feb. 26, 2011), https://www. espn.com $/ \mathrm{mlb} /$ columns/story?columnist=caple_jim\&id=6161420 [https://perma.cc/6Q7B-
} V2PE]. 
Judicial interference also detracts from the sports controversies fans and commentators discuss and debate from generation to generation.

The Kentucky Horse Racing Commission has focused on the argument that the Wests did not have a cognizable Fourteenth Amendment property interest in the first-place prize before the stewards posted the official order of finish. ${ }^{200}$ In March v. Kentucky Horse Racing Commission ${ }^{201}$ - a case cited by the Kentucky Horse Racing Commission ${ }^{202}$ - the Kentucky Court of Appeals held that the owner of Ethical Lawyer, a horse disqualified from a race on February 24, 2012, did not have a property interest in the purse because the horse was not awarded first place. ${ }^{203}$ As the Kentucky Court of Appeals in March noted, the horse owner's interest was at best a privilege and not a property interest protected by due process. ${ }^{204}$ The United States District Court for the Eastern District of Kentucky will likely follow the lead of March in the West litigation, as the situations are similarMaximum Security was never declared the official winner of the Kentucky Derby; thus, no property interest was created.

Further insights may be gleaned by comparing the Wests' alleged property interest in the Derby's outcome with cases resolving the question as to whether students have a protected property interest in their participation on school sports teams. Courts throughout the country routinely answer that there is no constitutionally protected property interest in participating in competitive sports. ${ }^{205}$

One of the more salient arguments for the Kentucky Horse Racing Commission is that, by participating in the Kentucky Derby, the owners of Maximum Security consented to the rules and regulations of the

200 Memorandum of Law in Support of Defendants' Motion to Dismiss at 8-12, West v. Ky. Horse Racing Comm'n, No. 5:19-cv-00211-KKC (E.D. Ky. June 8, 2019) [hereinafter Kentucky Horse Racing Commission's Memorandum of Law in Support of Defendants' Motion to Dismiss].

201 March v. Ky. Horse Racing Comm'n, No. 2013-CA-000900-MR, 2015 WL 3429763 (Ky. Ct. App. May 29, 2015).

202 Kentucky Horse Racing Commission's Memorandum of Law in Support of Defendants' Motion to Dismiss, supra note 200, at 10-12.

203 March, 2015 WL 3429763 at *2.

$204 I d$. at $* 3$.

205 See, e.g., Mitchell v. La. High Sch. Athletic Ass'n, 430 F.2d 1155, 1158 (5th Cir. 1970) ("The privilege of participating in interscholastic athletics must be deemed to fall in the latter category and outside the protection of due process."); Ryan v. Cal. Interscholastic Fed'n, 114 Cal. Rptr. 2d 798, 810 (Cal. Ct. App. 2001) ("Participation in interscholastic athletics, standing alone, is but one stick in the bundle of the educational process and does not rise to the level of a separate property or liberty interest to which a student is entitled and of which he or she cannot be deprived without due process."). 
Kentucky Horse Racing Commission, which state that horse racing is a privilege and not a right. ${ }^{206}$ As noted above, the applicable rules and regulations vest the stewards with the authority to make factual determinations as to interference and fouls. No right to an appeal is provided in those rules - a fact that presumably was known by all owners and trainers who had participating horses. In addition to the argument that horse racing in the state of Kentucky is not a right, it should also be noted that the participants in the Kentucky Derby have a duty to follow the rules of the race. Just as an insured person generally has a duty to read the insurance contracts they enter, ${ }^{207}$ the participants of the Kentucky Derby have an affirmative duty to avoid interference or a foul during a race. And if interference or a foul occurs, then the stewards have the general authority to make factual determinations. All the participants in the race arguably consented to this rule.

Perhaps the most compelling reason for upholding the official results of the 2019 Kentucky Derby is to serve the policy of promoting the finality of official outcomes. Protracted litigation concerning a judgment call at a sporting event detracts from the certainty sports fans have come to expect once an official winner is announced. It also detracts from the rich history of controversial decisions in other sports - from calls in baseball, such as the famous Don Denkinger call in Game Six of the 1985 World Series between the St. Louis Cardinals and Kansas City Royals, ${ }^{208}$ to calls in football, such as the famous "tuck rule" call in the 2002 AFC playoff game between the Oakland Raiders and New England Patriots. ${ }^{209}$ As the Illinois Court of Appeals aptly remarked in the Kline case, "The essence of horse racing is the immediate finality of declaring the winner." 210 For these reasons, courts will likely uphold the stewards' decision as to the official outcome of the 2019 Kentucky Derby.

206 Ky. REV. STAT. ANN. § 230.215(1) (West 2019) ("Further, it is hereby declared the policy and intent of the Commonwealth that the conduct of horse racing, or the participation in any way in horse racing, or the entrance to or presence where horse racing is conducted, is a privilege and not a personal right; and that this privilege may be granted or denied by the racing commission or its duly approved representatives acting in its behalf.").

207 See Nat'l Life \& Accident Ins. Co. v. Ransdell, 82 S.W.2d 820, 823 (Ky. Ct. App. 1935).

208 Doug Miller, Denkinger Cool with Reminders of Mistaken Call in '85 Series, MLB.COM (Oct. 20, 2014), https:/www.mlb.com/news/don-denkinger-players-recallblown-call-in-1985-world-series/c-99040244 [https://perma.cc/KA3G-FDCA].

209 Karen Given, The 'Tuck Rule' Game That Started a Dynasty ... and a Backlash, WBUR (Feb. 3, 2017), https://www.wbur.org/onlyagame/2017/02/03/patriots-tuck-rule [https://perma.cc/6MVQ-M6ZG].

210 Kline v. Ill. Racing Bd., 469 N.E.2d 667, 672 (Ill. App. Ct. 1984). 


\section{CONCLUSION}

The 2019 Triple Crown horse racing season has been nothing short of memorable and replete with oddities and rare events. Following the controversial outcome of the 2019 Kentucky Derby on May 18, 2019, viewers of the Preakness Stakes at Pimlico in Maryland saw an unusual event. Bodexpress, one of the horses competing in the race, threw off Hall of Fame jockey John Velaquez in the opening seconds of the race. ${ }^{211}$ Undeterred by the lack of a jockey, Bodexpress ran the entire length of the course without a jockey, and at several points legitimately vied for first place. ${ }^{212}$ Reporters wrote numerous articles about Bodexpress's determination to compete. ${ }^{213}$ The ending of the 2019 Kentucky Derby and the heroic run of Bodexpress illustrate that there is a fair amount of uncertainty in a horse race, and that what may appear to be strange events in horse racing may not be so strange after all.

This Article demonstrates that disqualification decisions in horse races are generally not as rare as is implied by the narrative surrounding the stewards' decision in the 2019 Kentucky Derby. Overall, courts have been reluctant to overturn stewards' decisions - even on due process grounds - which means a change in the outcome of the 2019 Kentucky Derby is very unlikely.

As the 2019 Kentucky Derby and 2019 Preakness Stakes demonstrate, "[a]nything can happen in horse racing." ${ }^{14}$ A racetrack may be muddy, a horse may be ill or not feel well on a particular day, or a horse may be extremely agitated at the gate-all these circumstances can affect the outcome of a race. It is this range of possibilities that makes horse racing a fascinating sport. No outcome is

211 ESPN News Services, Bodexpress Runs Entire Preakness Without Jockey, ESPN (May 18, 2019), https://www.espn.com/horse-racing/story/_id/26776938/bodexpress-runsentire-preakness-jockey [https://perma.cc/A4QN-U4RW].

$212 I d$.

213 See, e.g., Zach Brook, The Real Winner of the Preakness Was Bodexpress, the Jockey-less Horse, NBC SPORTS (May 18, 2019, 7:07 PM), https://www.nbcsports.com/ washington/other-sports/real-winner-preakness-was-bodexpress-jockey-less-horse [https:// perma.cc/88QR-XFFE]; David Ginsburg, Jockeyless Horse Steals the Show at the Preakness, Bos. GLOBE (May 18, 2019), https://www.boston.com/sports/sports-news/2019/ 05/18/jockeyless-horse-steals-the-show-at-the-preakness [https://perma.cc/N5UD-LGCU]; Hemal Jhaveri, The Real Winner of the 2019 Preakness Is the Horse That Ran Without a Jockey, USA TODAY (May 18, 2019, 7:30 PM), https://ftw.usatoday.com/2019/05/ preakness-bodexpress-ran-without-a-jockey [https://perma.cc/99CQ-M4QY].

214 Cohen, supra note 14. 
absolutely certain. And sometimes, even a long-shot horse - the "dark horse" 215 — will unexpectedly end up the winner. ${ }^{216}$

215 The term "dark horse" has been used in politics to describe a long-shot candidate. Generally, a "dark horse" is a long shot. See, e.g., William G. Ross, Presidential Ambitions of U.S. Supreme Court Justices: A History and an Ethical Warning, 38 N. KY. L. REV. 115, 167 (2011) ("Long gone is the era in which conventions would nominate 'dark horse' candidates or draft a nominee who had not sought the nomination.").

216 See David Hayes, Country House Wins 2019 Kentucky Derby as Shocking Dark Horse Amid Disqualification Controversy, FANDuEL (May 4, 2019), https://www.fanduel. $\mathrm{com} /$ theduel/posts/country-house-wins-2019-kentucky-derby-as-shocking-dark-horseamid-disqualification-controversy-01da2e1zknyq [https://perma.cc/HD8G-PQAW]. 
